\title{
Vladimir Yudin*
}

\section{TYPES AND SPECIAL ASPECTS OF AGRO RISK}

\begin{abstract}
A b s t r a c t: The article is devoted to pure agrarian risks. Among them: climatic and weather factors; production and technology riski; risk of sanitary norms breaking; risk of agrarian commodity storage, transportation and realization; risk of land rights loss. The article aim is to identify risks in the Ukrainian agriculture and their classification, as well as describe the most influential risks inherent in agriculture, taking into account also the international experience. The author separates specific risks inherent to Ukraine: risk of state financial assignation and insurance compensation non-payment.
\end{abstract}

K e y w o r d s: agrarian risks, weather conditions, sanitary norms, production risk, technological risk, insurance risk.

Ye 1 C o d e: Q13, Q10

\section{INTRODUCTION}

The impact of risks on farm activities is one of the greatest among other industries. Moreover, the interdependence and impact of global economic and political trends on agricultural (hereinafter - agro) production prices and climate change together with anthropogenic factors requires constant monitoring of new risks and ways to manage them. Therefore, classification of agro risks and their detailed analysis provided agro producers proper tools responding to the relevant risk. The thematic justification in the analysis of agro risks and their minimization is also practically assured given it to the potential of Ukrainian agricultural land and the steady world population increase and the increase of some crops usage for technical purposes.

The questions of identification, classification, analysis of agro risks and their management were the research subject of some Ukrainian and foreign scientists, primary economics representatives. Among Ukrainian scientists should provide the following: Kyrylyuk E.M. [6], Nepochatenko O.A. [10] Nychyporuk O.Y. [11], Prokopchuk O.V. [15], Saprykina O.M. [21] etc. Among foreign -

\footnotetext{
* Department of Finance and Credit Uman National University of Gardening
} 
Svoinski E. [23], Palinkas P., Zekel K. [27] and others. The most noteworthy research is the research of O.Y. Nychyporuk, which is devoted to risks in agriculture, but the work was done in 2002 and now there are many changes in terms of agriculture.

\section{RISK TO AGRICULTURAL}

There are many risks that can arise at different stages of operation in any sector of economy and any single entity. The following risks referred to the general risks of economic (business) activities: credit, currency, market, operational, production, personnel, legal and others. However, each has its own scope, risks unique to it, and too concerned with agricultural production. That's why we suggest separating this type of risk as a pure agricultural risk. Agricultural risks have certain features in comparison with risks in other areas of the economy. First, the agro production risks related to climatic conditions and seasonality of production, a prolonged period of production and difficulty in products storage and their rapid deterioration that requires immediate processing or marketing.

We propose to refer following risks to agricultural:

1) Climate and weather conditions;

2) Technological conditions of production;

3) Regulatory requirements for safety and quality;

4) Diseases of animals and plants;

5) Particular issues associated with storage, transportation and realization of production;

6) Rights to land plots.

1. The risk of climate and weather conditions are: spring frost; extreme cold without snow which lead to winterkill of crops, trees and bushed; hail; ice; drought; showers; storm; hurricane; flooding; rural land-water; lightning, earthquake; avalanche. These risks are virtually impossible to predict as the weather forecasts are effective for 1-2 weeks and predictions of natural and self-inflicted disasters are even less reliable. According to the research of Saprykina O.M. the yield change of $15.7 \%$ only formed by agronomic factors and the rest of variation related to climatic factors (84.3\%) [21]. Id Est the climatic conditions in particular are essential in agriculture.

All above-mentioned types of risk may be subject of insurance and insurance company itself take the decision which risk to include into the list of risks to be insured. Only some insurers insure all of the above listed types of risks, for example, "Oranta" insures all these types of risks in complex insurance of agro crops (the part of the cost for planting paid out) and complex (Multi-Peril Crop Insurance) insurance of future crops (the part of the cost yield indemnified). Under the current law only those risks could not be insured the insurance events for which have occurred, such as the presence of certain diseases in animals. To insure such animals against these diseases is already impossible because such an agreement will be considered null and void (Article 998 of the Civil Code of 
Ukraine [26]). In addition, under the current law the agro crops harvest that did not give a crop for three years in their cultivation and perennial plants harvest of fruiting age, which were not given the crop over the past five years, are not subject to insurance with state support. However, insurance companies also do not insure crops and harvest against forest fires.

Consequences of serious man-made disasters (such as the Chernobyl accident) that can seriously affect the purity of the soil, air and water, contamination or pollution of chemical compounds, such risks are not insured by any insurance companies.

2. The risks of technological production conditions include the following:

1) risks of violation of technological conditions of production, approved:

a) on regulatory level (sanitary regulations, national standards);

b) by the enterprise (specifications, cultivation technology of appropriate crops).

2) risks associated with the cost of operational expenses, such as changes in correlation of relative prices for resources and agro production during the production period which show itself through inequation of prices for agro and industrial products used in agro production upward latter [22];

3 ) risks associated with the specialization selection, which would meet the soil and climatic zones in the first place, a stable demand, and a market for this type of product in the second place.

Violation of technological growth conditions of agro production or its processing can lead to various consequences, including: 1) a total or partial loss of the crop; 2) non-reimbursement of insurance payments at approach of insurance event; 3) removal of sales on the domestic market or loss of the possibility to import products; 4) claims of customers or third parties (including violation of rules of fields processing with chemicals).

Each agro producer shall meet certain statutory requirements stipulated quality and safety of agro raw materials and food products. Ukraine signed the Agreement on Sanitary and Phytosanitary Measures in 1994 [24], which have a dual purpose: 1) to protect the country - WTO members against unfair competition due to excessive use of certain pesticides (herbicides, insecticides, fungicides, etc.); 2) to ensure the health of its population.

Significant variation of agro production amount together with inelastic demand for agro production is the cause of unstable prices for it [23, p. 43]. In addition, the risks associated with the increased cost of production expenses are among the most pressing due to inequation of prices for industrial and agro products. According to research of Nychyporuk O.Y. the profit of agro enterprise is most sensitive to changes in prices for plant protection products, labor expenses raise, prices for seeds, and to a lesser extent, the impact on enterprise profit has the price for fuel, lubricants and fertilizers [11, p. 129]. Below we propose Table 1 and Table 2 with illustrate the structure of production costs for the years 20142015 for basic agro crops: wheat and corn. 
Table 1. The average production cost of wheat at Agro holdings, UAH/ha

\begin{tabular}{|c|c|c|c|c|c|c|c|}
\hline Year & Seeds & $\begin{array}{c}\text { Mineral fertil- } \\
\text { izers, } \\
\text { herbicides }\end{array}$ & $\begin{array}{c}\text { Oil prod- } \\
\text { ucts }\end{array}$ & $\begin{array}{c}\text { Services } \\
\text { expenses }\end{array}$ & $\begin{array}{c}\text { Other } \\
\text { material } \\
\text { costs }\end{array}$ & Salary & $\begin{array}{c}\text { Other } \\
\text { direct } \\
\text { costs }\end{array}$ \\
\hline 2014 & 700 & 1000 & 800 & 800 & 600 & 200 & 2000 \\
\hline 2015 & 850 & 2200 & 900 & 1000 & 900 & 350 & 2600 \\
\hline
\end{tabular}

Source: developed by the author based on the current Archives of Statistical Committee of Ukraine for 2014-2015 years.

Thus, the costs of the company in growing wheat in 2015 increased by $48.5 \%$ compared with 2014 , but profitability also increased by $25,4 \%$.

Table 2. The average production cost of corn at Agro holdings, UAH/ha

\begin{tabular}{|c|c|c|c|c|c|c|c|}
\hline Year & Seeds & $\begin{array}{c}\text { Mineral fertil- } \\
\text { izers, } \\
\text { herbicides }\end{array}$ & $\begin{array}{c}\text { Oil prod- } \\
\text { ucts }\end{array}$ & $\begin{array}{c}\text { Services } \\
\text { expens- } \\
\text { es }\end{array}$ & $\begin{array}{c}\text { Other } \\
\text { material } \\
\text { costs }\end{array}$ & Salary & $\begin{array}{c}\text { Other } \\
\text { direct } \\
\text { costs }\end{array}$ \\
\hline 2014 & 1850 & 1000 & 700 & 1500 & 700 & 300 & 1900 \\
\hline 2015 & 1900 & 2200 & 800 & 1500 & 900 & 500 & 2200 \\
\hline
\end{tabular}

Source: developed by the author based on the current Archives of the Statistical Committee of Ukraine for 2014-2015 years.

The costs of corn cultivation in 2015 increased by $20.5 \%$, though the profitability of corn growing increased by $25.4 \%$. However, the profitability of conventional agro enterprises in comparison with agricultural holdings is on $4 \%$ in average lower.

Risks associated with the right choice of specialization associated with some differences in climatic conditions of different regions of Ukraine and significant difference in the quality and suitability of soils for different agro crops. For example, in the south of Ukraine (steppe zone) it is not profitable to grow sugar beets, and in the area of the Carpathians - wheat. The risks associated with supply and demand for different agro products solved by diversifying production and study of the structure of competitive businesses agricultural production. Therefore, knowledge about what crop is planned for cultivation by different farmers, although it is currently confidential, but it would have served as a positive factor for the distribution of crops between different producers, reduce the possible market glut with respective crops and thus reduce the producers' risk of losses and food security of the country.

3. The risks associated with regulatory requirements for safety and quality are partly related to the risks of technological production conditions, but is also a risk that the regulation in terms of safety and quality, which can significantly affect the competitiveness and innovation and may require innovations 
in engineering and technology. Unfortunately, the legislation does not specify maximum concentration of corresponding compounds in agro soil that would provide additional assurance of product quality and stimulate agro enterprises to the rational use of agro lands, even in the last years of the term of the land (shares) lease.

In the 1990s, the amount of residual pesticides in foods, plants and animals has increased (compared to 1960s years) by more than 9 times [2, p. 48]. This threatens both the agro enterprises and consumers of such products and even the entire population as agrochemicals easily fall into the ground and underground waterways. Of course, agro enterprises cannot work without the use of fertilizers and pesticides, but the latter is particularly conducive to the formation of the stability of living organisms against which they are used and that's why, for example, in the US despite a tenfold increase in pesticide use for four decades, total losses of agro production from various pests, weeds and diseases have not decreased, but rather increased from 31 to $37 \%$ [7]. In Ukraine the average potential loss of major agro crops production due to pests' impact is on average $25-30 \%$, which is strongly dependent on the type of agro crops (wheat $-27 \%$ fruit - 48\%) [25, p. 3].

Ukrainian legislation is inconsistent with the regulation of health standards. For example, from July 1997 to May 2015 in Ukraine subject to mandatory certification was almost all food products, both domestic products and imported [20] and now the subject to mandatory certification are only baby food, alcohol and tobacco [ 18], which will adversely affect the competitiveness of producers with high quality products. In addition, despite the existence of public health standards on quantity of nitrates in food, these rules are often violated because almost all foods are currently not subject to mandatory certification. Moreover, the national standards in the field of food products such as GOST (USSR standards) are not binding, and Ukrainian standards GOST allow you to change recipes to specifications (TU), approved by the manufacturer. On the one hand, this is the risk to consumers, not producers, and on the other hand, it does not encourage manufacturers to introduce advanced production technologies to supply to the world market not only raw materials, but also the processing industry [10], which would provide for the country's further added costs and jobs to citizens.

4. Risks associated with the disease of animals and plants. The most dangerous for both animals and plants are infections (viral, bacterial, fungal, parasitic, prion). These are the types of diseases that are easily transmitted to other members of the relevant class can quickly become an epiphytotic or epizootic (epidemic). Given that these types of risks can hardly be insured, for some exceptions, in Ukraine only few Insurance companies can insure crops against epiphytotic diseases with state support, they are among the most dangerous for agricultural producers. As for the animal situation it is even more acute, there- 
fore the means of infectious diseases risks minimizing is vaccination of animals against diseases for which developed vaccination, as well as compliance with sanitary norms and rules for their maintenance, the timely detection of outbreaks of the relevant disease and their identification (diagnosis), providing quarantine measures if there is such a need.

Among the negative effects that entail quarantine measures established by the regulations of the State veterinary service is forced slaughter and utilization of livestock, pigs, hens [4], etc. for the purpose of non-proliferation of especially dangerous diseases including prevention of human infection - consumers of the production in case if disease is transmitted to humans (leprosy, Siberian ulcer, etc.). Compensation of the average market value of animals, which are subject to emergency slaughter, is carried out only in the case of insurance with state support and the actual availability of budget funds for appropriate purposes. The subject to compulsory insurance against forced slaughter now is only breeding animals used for breeding purposes [19].

In the case of mortality (death) of animals from anthrax, rabies, trichinosis, emkaru, glanders and other highly dangerous infectious diseases, and diseases of unknown etiology, their corpses are subject to compulsive thermal disposal (incineration) [9], carried out by the enterprise who owned these animals (according to the veterinary Regulation No 232) [13].

5. Risks associated with the peculiarities of storage, transportation and sales. For storage of plant products, particularly cereals, legumes and oil needed significant funds for the construction of elevators (grain storage barns) that can afford only large agro holdings. The main owners of grain elevators in Ukraine are reflected in a Table 3 with total revenue of holdings. Of course, some companies artificially removed from the holding structure and the parent companies registered in offshore zones are not always possible to follow, and the consolidated balance sheet under Ukrainian law are not required to publish by holdings, so the proceeds can be underestimated by individual companies.

The largest owners of grain elevators are "Kernel", "Glencore", "Nibulon" "MHP", "Ukrlandfarming". Location of agro holdings on capacity and the amount of elevators is almost proportional to the amount of revenue in other words the higher revenue; the greater the power of elevators, excluding, for example, Agro Holding «Mriya», which currently faces financial difficulties. Speaking of international companies such as Bunge, Glencore, Alfred S. Toepfer their revenue is estimated, taking into account only the proceeds received from the sale of products from Ukraine. 
Table 3.The grain elevators capacity and profit of Agro holdings

\begin{tabular}{|c|c|c|}
\hline Agro holding & $\begin{array}{c}2015 \text { year profit,- } \\
\text { million } \$\end{array}$ & $\begin{array}{c}\text { General holding capacity of } \\
\text { grain elevators, million } \mathrm{t}\end{array}$ \\
\hline Kernel & 2329,5 & 3 \\
\hline Glencore & 1705 & 1,8 \\
\hline Nibulon & 1946,4 & 1,6 \\
\hline Mironivsky Khliboproduct & 1183,3 & 1,1 \\
\hline Ukrlandfarming & 937,5 & 1 \\
\hline Mriya & 68 & 0,8 \\
\hline Alfred C. Toepfer & 883 & 0,7 \\
\hline Bunge & 753 & 0,6 \\
\hline Agrotrade & 131,5 & 0,5 \\
\hline Astarta & 347,5 & 0,4 \\
\hline
\end{tabular}

Source: developed by the author based on the current Archives of the Statistical Committee of Ukraine for 2015 year.

There are also companies which primary activity is to provide services to other agro holdings and agro enterprises with storage, drying, cleaning and transportation of grain, oil and legumes, for example Agro Holding "Prometheus". Despite the fact, that in recent years the agricultural market participants actively invest in the development of logistics, a shortage of grain elevators, often forcing small producers to sell grain at low prices or pay unnecessarily high prices for storage [1, p. 12]. The average cost of storage of 1 ton of grain at the beginning of 2016 was about 57 UAN.

The cost of grain elevators equals to millions of dollars, such as at the 2016 the NCH Capital spent \$15 million to build and equip Zhmerinsky elevator capacity of 40000 tones. However, the construction of elevators is quite profitable investment, besides its construction does not require the procedure of issuing permits for construction and provides a simplified procedure for the examination project [3].

The risks associated with the realization of agro production include legal risks regarding the validity and security of transactions, as well as the risks of accidental loss or damage of goods and so on. Apart from that, there are a lot of problems in Ukrainian institutional infrastructure of the commodity and stock trading. Despite the large amount of exchanges, the share of agreements signed on them is minimum, particularly in the agricultural exchanges sold only $1 \%$ of agro production out of a total [6, p. 45-54]. Moreover, even these agreements are often concluded to comply with legal requirements for obligatory registration of foreign economic contracts, which lasted from 2000 to 2012 [16], often such agreements were fake, i.e. off-exchange trades registered as a stock. 
Such registration had no positive effects but only picked the producers exporting commission of $0.2 \%$, which on large contracts can be a substantial sum.

6. Risks associated with land rights. In Ukraine remains in force a moratorium on alienation land of agro production commodity, that prolonged for many times. This moratorium has positive and negative sides. The positive aspects include the fact that Ukraine has not created land estates. The negative - the absence of land market, which would provide an opportunity to receive loans by small farmers secured on their own land plots. Consequently, in Ukraine the amount of small agro businesses that use credit funds does not exceed $20 \% \mathrm{com}$ pared with $64 \%$ in Europe and the US [27, p. 67].

For large agro holdings there are problems with contracts formation and constant renewal of leases on land plots. If the owners of land plots can find better lease terms, they may require early termination of the lease with the release of their land parcel that can be physically within the land mass, which prevent mechanized cultivation of the land. However, it should be noted that signed leases seldom allow landowners to prematurely terminate such contracts. Moreover, often such agreements provides for automatic prolonging of the contract for the same period for which it was originally signed, if the landlord does not send a written letter to the tenant (return receipt requested) to terminate the contract within one month after expiry agreement. It is possible to prematurely terminate the lease unilaterally only in court under the following legal grounds: non-purpose use of land, non-payment of rent, infliction of environmental damage to the land plot following tenant activity.

There is another specific risk in Ukraine for agro enterprises, in particular the risk of non-payment of budgetary support, which is planned for the relevant fiscal period. The fact that any provided state payments through the agro producers' support, such as payment of premiums or interest on loans, are performed post-factum. This means that producers pay insurance premiums and loans by themselves and the State bodies upon availability of funds in the relevant budget pay back money to producers after passing bureaucratic procedures, so most of agro businesses do not receive funds for which they are intended. In fact, Ukraine financial support of agro producers per 1 ha, cost-cutting of loans [12] and livestock support are carried out only on large agro holdings. A support program for small farms, which cultivate up to 500 hectares (their share made up to $86 \%$ out of total), do not even have a mechanism for implementation, in particular the procedure for providing, sources of financing and so on.

Regrettably, agro producers face problems with insuring the future crop or other types of insurance. Insurance companies quite often do not pay insurance compensation at approach of insurance event, ignoring its presence or under formal legal basis, inasmuch as the National Commission of financial services regulation has no control over the quality of insurance services provided by insurance companies. In Ukraine, there is no reliable mechanism for deducting future crop size and cost, so insurers mostly only cover production costs rather than the planned profit of agro enterprises. In addition, when insuring agro risks insurance companies use very large deductible (40-60\%), which often deprives 
agro enterprises of an economic sense to conclude such insurance contracts. A public-private partnership that is stipulated by the Law of Ukraine "On special aspects of agricultural production insurance with state support" [17] and even the creation of the Agricultural Insurance Pool measures are ineffective because the state does not allocate funds for the full implementation of this insurance model [15]. Statistics show that as of today only $3-5 \%$ of all agricultural producers insure their crops [8]. Moreover, even those who insure their crops tend to carry it to obtain credit.

\section{CONCLUSIONS AND PERSPECTIVES FOR FURTHER RESEARCH}

The risks, which affect the agro production, could be divided into two groups: 1) general risks inherent to all businesses; 2) pure agricultural risks. The last include: - climatic and weather conditions; - technological conditions of production; - regulatory requirements for safety and quality; - diseases of animals and plants; -special aspects of storage, transportation and marketing; - the right to land. Ukraine has specific risk of non-payment of state support to agro enterprises and the risk of non-payment of insurance compensation. In further studies, it is advisable to investigate the degree of influence of each of these risks on the operations of agricultural enterprises.

\section{REFERENCES}

Agrarian sector of Ukraine: trends, members, reform prospects. Nova Ukraina. Institute of Strategic researches. - Kiev. -2015 . -28 p.

Glossary on Chemistry // Y. Opeyda, O. Shvayka. Institute of Physical Organic Chemistry and Coal named L.M. Litvinenko NAS Ukraine, Donetsk National University — Donetsk: «Veber», 2008. $-758 \mathrm{p}$.

Glotova I.E. Economics for elevator: current approaches allow making a profitable business on elevators construction / Irina Glotova. - The Ukrainian Farmer - 2015. - June [Electronic resource]: Team review:

http://sampo-ukraine.com/uploads/MEPU_AGI_ekonomika_dlya_elevatora_june_2015.pdf Instruction on preventive measures and control of Anthrax disease of animals: Order of the State Department of Medicine and Ministry of Agriculture of Ukraine dated January 25, 2000

№ 4 // [Electronic resource]: Team review:

http://search.ligazakon.ua/1_doc2.nsf/link1/REG4357.html;

Guideline for the prevention and elimination of diseases in animals FMD: Order of the Chief State veterinary inspector of Ukraine dated December 7, 2001 № 99 // Official Bulletin of Ukraine. - 2001. - № 50. - Art. 2253.

Kyrylyuk E. M. Formation of economic relations between agricultural producers and intermediary structures in Ukraine: Monograph / E. M. Kyrylyuk. - Cherkassy: Publisher CNU named Bohdan Khmelnitsky, 2009. - 212 p.

Kurdyukov V.V. Pesticides effect on vegetational and animal organism/V.V. Kurdyukov - M.: Kolos, 1982. - 128 p.

Lobenko O. M. Agro insurance as financial instrument of risks management at agro production / Lobenko O. M., Zolotar Y. V., 2015 // [Electronic resource]: Team review: file://D:/ Мои\%20Документы/5951-11835-1-SM.pdf

Marvenetska V. Animals mortality/ V. Marvenetska // Balance-Agro. Economic branch audit. - 
2014. - № 37 (409). - October 6. - P. 21-24.

Nepochatenko O.O. The competitive environment and economic development trends of agro farms

/ O. O. Nepochatenko, C. A. Ptashnik // Scientific notes of National University "Ostroh Academy". - Series of "Economy". - Addition 1 (29). - 2016. - P. 48-54.

Nychyporuk O. Y. Risks in Agriculture: identification, assessment, management: dissertation of

Cand. Sc. Economy: 08.07.02 / Nychyporuk O. Y. - K., 2002. - 244 p.

The procedure for using funds provided by the state budget for financial support measures in agriculture through cheaper loans: CMU 29 April 2015 r. Number 300 // Official Bulletin of Ukraine. - 2015. - № 40. - Art. 1191.

Rules on improvement and maintenance of existing mortality digesters and bio thermal pits and disposal for animal carcasses settlements in Ukraine, approved by the State Veterinary Committee dated 27.10 .08 p. № 232 // [Electronic resource]: Team review: http://www. dsesu.gov.ua/ua/normativna-pravova-baza/sanitarni-pravyla-i-normy?start $=80$

On amending and ceasing to be terminated of some decrees of the Cabinet of Ministers of Ukraine on registration of foreign economic contracts: Cabinet of Ministers of Ukraine // Ukraine Official Journal. - 2012. - № 91. - Art. 3672.

Prokopchuk O. T. Special aspects of agro risks insurance in different countries / O. T. Prokopchuk, Y. V. Ulyanich, V. P. Bechko // Contemporary problems in economy. - 2014. - № 13. - P. 46-53.

On urgent measures to stimulate production and development of grain market: Decree of the President of Ukraine on June 29, 2000 № 832 // Official Gazette of Ukraine. - 2000. - № 26. - Art. 1090.

On peculiarities of agricultural products insurance with state support: Law of Ukraine 09.12.2012 № 4391-VI // Journal of Supreme Council of Ukraine. - 2012. - № 41. - Art. 491.

On approving the list of products subject to mandatory certification in Ukraine: State Committee of Ukraine for Technical Regulation and Consumer Policy dated February1 2005 № 28 (with changes and additions) // Official journal of Ukraine. - 2005. - № 19. - Art. 1006.

On approval of rules and mandatory insurance of animals in case of death, destruction, forced slaughter, diseases, natural disasters and accidents, the Cabinet of Ministers of Ukraine dated April 232003 № 590 // Official journal of Ukraine. - 2003. - № 17. - Art. 780.

On approval of Rules for mandatory certification of food: State Committee of Ukraine for Standardization, Metrology and Certification dated June 21997 № 322 // Official journal of Ukraine. - 1997. - № 29. - Art. 123.

Saprykina O. M. Analysis of farm production risks / O. M. Saprykina // Collection of Scientific Articles of the Tauride State University of Agro technology (economic science). - 2014. № 2(26). - P. 194-199.

Satir L. M. Concerning the problem of parity prices for industrial and agricultural products / L. M. Satir // Economy and State. - 2013. - № 2. - P. 35-37.

Svoinski E. Agro risks management in Poland: dissertation of Cand. Sc. Economy: 08.00.05/ Svoinski Eugeniusz. - Kursk, 2009. - 318 p.

The WTO Agreement on Sanitary and Phytosanitary Measures dated April 151994 // Official journal of Ukraine. - 2010. - № 84. - Art. 2989.

Phyto pharmacology: Textbook / M. D. Evtushenko, F. M. Marutin, V. P. Turenko etc.; under the editorship of Professor M. D. Evtushenko, F. M. Marutin. - K.: Vischa osvita, 2004. - 432 p.

Civil Code of Ukraine dated January 162003 // Journal of Supreme Council of Ukraine. 2003. - №oo 40-44. - Art. 356.

Szekely Csaba, Palinkas Peter Agricultural Risk Management in the European Union and in the USA/ Studies in Agricultural Economics. - 2009. - \# 109. - 55-72 p. 